\title{
Food poisoning outbreak investigation in Dewachefa woreda, Oromia Zone, Amhara Region, Ethiopia, 2018
}

\author{
Mengistie Kassahun ${ }^{1 *}$ and Sewnet Wongiel ${ }^{2}$
}

\begin{abstract}
Objective: To verify occurrence of outbreak, describe cases in person, time and place, and identify factors associated with the outbreak. Unmatched case control study was conducted with sample size 175 in Dewachefa woreda from April 24 to May 02/2018. Data were collected with structure questionnaire. Collected data were entered into Epi Info version 7 and exported to statistical package for social science version 23 for analysis. Analyzed data were presented by texts, table and graphs.

Result: A total of 35 food poisoning cases with no death were reported. The overall attack rate was 25.58/10,000. Eating raw meat [adjusted odd ratio $(A O R)=11.04 ; 95 \% \mathrm{Cl} 3.03-40.17$ ], drinking raw milk $\mathrm{AOR}=4.81 ; 95 \% \mathrm{Cl} 1.42-16.23$ ), $\operatorname{sex}(\mathrm{AOR}=3.57 ; 95 \% \mathrm{Cl} 1.37-9.32)$, hand washing before eating ( $\mathrm{AOR}=13.42 ; 95 \% \mathrm{Cl} 3.63-49.72)$ and Sources of drinking water $(A O R=11.50 ; 95 \mathrm{Cl}$ 1.96-67.49) were significantly associated with food poisoning. Food poisoning outbreak were occurred in Dewachfa woreda. Sex of study participants, eating raw meat, drinking raw milk, hand washing before eating, materials use to clean food utensils and source of drinking waters were factors of food poisoning. Proper food handling should be recommended.
\end{abstract}

Keywords: Food poisoning, Outbreak, Dewachefa woreda

\section{Introduction}

Food poisoning is an acute illness with recent consumption of contaminated food or water. It can be infectious or noninfectious. Infectious food poisoning is caused by eating food or water contaminated by bacteria, viruses, parasites or their toxins [1]. It is also called a food born disease $[2,3]$. The most common symptoms of food poisoning are nausea, vomiting, abdominal cramps and diarrhea [1-4]. Other symptoms that may occur are fever and abdominal pain [1]. Food poisoning outbreak is the incidence of two or more cases of a similar foodborne disease resulting from the ingestion of a common food [5].

The most common microorganisms that cause food poisoning are Norvirus, Salmonella, Clostridium

\footnotetext{
*Correspondence: mengesh2009@gmail.com

${ }^{1}$ Resident of Field Epidemiology, Department of Epidemiology and Biostatistics, College of Medicine and Health Science, Bahir Dar University, Bahir Dar, Ethiopia

Full list of author information is available at the end of the article
}

perfringens, Campylobacter and Staphylococcus aurous $[1,5]$. Hospitalizations due to food poisoning are mostly caused by Salmonella, Norvirus, Campylobacter, Toxoplasma gondii and Escherichia coli [1]. Salmonella, Toxoplasma gondii, Listeria monocytogenes, Norvirus and Campylobacter can cause deaths $[1,2]$.

Depending on the cause of food poisoning, the duration of the majority of food poisoning usually ranges from a few hours after exposure to contaminated food or fluid to several days [1].

Eggs, poultry, and meats, unpasteurized milk, cheese, raw or unwashed fruits and vegetables, nuts and spices are most commonly associated with food poisoning illness $[1,4]$. Factors associated with food poisoning outbreaks also include consumption of inadequately cooked or thawed meat or poultry, cross-contamination of food from infected food handlers, presence of flies, cockroaches, rats, in the food environment that acts as vectors of the disease [6-8].

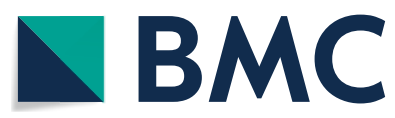

(c) The Author(s) 2019. This article is distributed under the terms of the Creative Commons Attribution 4.0 International License (http://creativecommons.org/licenses/by/4.0/), which permits unrestricted use, distribution, and reproduction in any medium, provided you give appropriate credit to the original author(s) and the source, provide a link to the Creative Commons license, and indicate if changes were made. The Creative Commons Public Domain Dedication waiver (http://creativecommons.org/ publicdomain/zero/1.0/) applies to the data made available in this article, unless otherwise stated. 
Globally, 48 million people get sick from a foodborne illness, 128,000 are hospitalized, and 3000 die in each year [9]. Even if the highest number of cases and deaths of food poisoning occur in developing countries [6], there was limited evidence on verification of occurrence the outbreak, the descriptions of the cases and the predictors of food poisoning outbreak in the study area. This investigation aimed to verify occurrence of outbreak, describe cases in person, time and place and identify factors associated with the outbreak in Dewachefa woreda.

On Tuesday morning, April 24/2018, Oromia Zone health department in Amhara Region was contacted by Kemisie General Hospital. In the telephone conversation, Hospital Public Health Emergency Management (PHEM) focal person told Zonal PHEM officer that seven cases of food poisoning had visited Kemisie General Hospital from Qelo and Gure kebeles who were participants of lunch ceremony. Within $30 \mathrm{~min}$ of notification of the outbreak by the hospital, four Field Epidemiology Residents, Dewachefa woreda health office and Zonal health department PHEM officers visited the reported hospital and checked the existence of an outbreak. Two Field Epidemiology Resident, woreda health office and Zonal health department PHEM officers visited the village where food poisoning cases outbreak occurred. Other two Field Epidemiology Residents stayed in the hospital to see whether the case is increasing or not.

\section{Main text Methods \\ Study setting and period}

Unmatched case control study was conducted from April 24 to May 02/2018 among lunch ceremony participants in Qelo and Gure kebeles, Dewachefa woreda, North-East of Ethiopia. The woreda is located about $325 \mathrm{~km}$ from Addis Ababa (the capital city of Ethiopia) and $555 \mathrm{~km}$ from Bahir Dar (the capital city of Amhara Region). The total population of the woreda was 151,645. The woreda is administratively divided into 26 kebeles. There are 7 health centers and 26 health post in the woreda. Gure and Qelo kebeles have total population 6001 and 7684 respectively [10]. There was lunch ceremony in Qelo and Gure kebele. The participants were from Qelo and Gure kebeles. About 162 and 50 people were participated in Gure and Qelo kebeles respectively. The outbreak was investigated among lunch ceremony participants in Gure and Qelo.

\section{Sample size and sampling techniques}

All cases from the two kebeles who participated in lunch ceremony were included in the study with a ratio of one case to four controls. The total sample size was 175 (35 cases and 140 controls). Controls were recruited among participants of lunch ceremony who have not ever an acute illness or sudden onset of abdominal pain, with or without diarrhea, vomiting and nausea. The controls were selected by lottery method simple random sampling in each Kebles.

\section{Measurement}

Data were collected from both Kemisie General Hospital and house-to-house search for food poisoning case. Structured questionnaires were used to collect data using face to face interview technique by 4 Field Epidemiology Residents. All food poisoning cases that came from Dewachefa woreda to Kemise General Hospital were interviewed. The data were collected using standard questionnaire. Similar codes were written on the cups with questionnaires and the laboratory request formats. Stool samples were collected from 7 food poisoning patients in clean dry cup. These samples were examined using wet mount preparation in Kemise General Hospital. A drop of fresh physiological saline was placed on a clean slide approximately $1 \mathrm{~g}$ of stool sample was added. The preparations were covered with cover slips and examined under microscope for the presence or absence of parasites or motile bacteria. In another procedure, a small spot of the stool specimen was placed in a drop of $0.05 \%$ methylene blue solution on a clean glass slide for each sample to examine it for cellular exudates.

\section{Statistical analysis}

Data was entered using EPI-info 7 and analyzed by SPSS version 23. ArcGIS was used for describe the case by place through dots on map. After data cleaning and recoding both descriptive analysis was under taken. Bivariable analysis was done. $\mathrm{p}$-value $\leq 0.25$ was included in multivariable analysis. In multivariable analysis p-value $<0.05$ was considered significance. Finally results presented in the form of text, tables and figures.

\section{Result}

\section{Descriptive epidemiology}

Distribution by person A total of 35 food poisoning cases with no death and 140 controls that fulfill standard case definition were included in the investigation. The median age of the cases was $25+11.84$ standard deviation (SD) year and that of the controls was $28+14.54$ years. Fifteen $(42.9 \%)$ of the cases and 95 (67.9\%) of controls were 15-44 years old. Three-fifths, 21 (60\%), of cases were male whereas 75 (53.6\%) of controls were female. All cases have the symptom of vomiting, abdominal cramps and fatigue. Thirty four (97.1\%) of cases had history of nausea and diarrhea. The cumulative attack rate was $16.5 \%$. More than half, 20 (57.1\%), of cases and three-fourth, 105 (75\%), of controls were married. 
Regarding to educational status, 16 (45.7\%) of cases and 95 (67.9\%) of controls had no formal education. More than half, $20(57.1 \%)$ of cases and $80(57.1 \%)$ of controls were farmer (Table 1 ).

Thirty (85.7\%) of cases and 130 (92.9\%) of controls were participated in lunch ceremony. Three-fifths, 21 (60.0\%), of cases and $115(82.1 \%)$ of controls were eating raw meat. Regarding to milk drinking, 23 (65.7\%) of cases and 76 (54.3\%) of controls were drinking raw milk (Table 1$)$.

Thirty (85.7\%) of cases and 110 (78.6\%) of controls had latrine access. Nearly two-thirds, 22 (73.3\%), of cases had been using latrine. The Majority of cases, $30(85.7 \%)$ had no hand washing practice after defecation whereas 100 (71.4\%) of controls had hand washing after defecation. Furthermore, 20 (57.1\%) of cases had no hand washing practice before eating. Twenty five (71.4\%) of cases and $85(60.7 \%)$ of controls had practice of disposing house hold solid waste on open field (Table 1).

Regarding to water source, 30 (85.7\%) of cases and 105 (75.0\%) of controls used pipe water for drinking. More than two-thirds, 25 (71.4\%), of cases and 95 (67.9\%) controls did not treat water with chemicals/boil for drinking (Table 1).

Distribution of cases by place The outbreak was occurred in Gure and Qelo kebeles, Dewachefa. Regarding to the cases distribution, $28(80 \%)$ of cases were from Gure Kebele. The attack rates of the outbreak in Gure and Qelo Kebeles were $17.3 \%$ and $14 \%$ respectively.

Distribution of cases by time Most cases had onset of symptom on April 26/2018 in which the outbreak was ended (Fig. 1).

\section{Laboratory investigation}

The results of all wet mount preparation showed that there was no seen parasite or motile bacteria whereas all methylene blue preparation results showed that smaller number pus cells of 20 per high power field were found.

\section{Analytical study}

In bivariable analysis sex of study participants, eating raw meat and drinking raw milk, hand washing after defecation and before eating, methods/types using to clean food utensils, way of disposing household garbage, source of drinking water use and access of latrine had p-value less than or equal to 0.25 and these variables were included in multivariable analysis.

In multivariable analysis, sex of study participants, eating raw meat, drinking raw milk, hand washing before eating, materials use to clean food utensils and source of drinking waters were significantly associated with food poisoning (Table 2).
Table 1 Characteristics of study participants in Dewachefa woreda, Oromia Zone, Amhara Region, Ethiopia, 2018

\begin{tabular}{lll}
\hline Characteristics & \multicolumn{2}{l}{ Respondents status } \\
& Cases & Controls \\
Nercentage & & Number Percentage \\
\hline
\end{tabular}

Age in year

$\begin{array}{lrrrr}<5 & 2 & 5.7 & 0 & 0.0 \\ 5-14 & 6 & 17.1 & 30 & 21.4 \\ 15-44 & 15 & 42.9 & 95 & 67.9 \\ \geq 45 & 12 & 34.3 & 15 & 10.7 \\ \text { Sex } & & & & \\ \text { Male } & 21 & 60.0 & 65 & 46.4 \\ \text { Female } & 14 & 40.0 & 75 & 53.6\end{array}$

\section{Education status}

$\begin{array}{lllll}\text { Not eligible } & 7 & 20.0 & 5 & 3.6\end{array}$

$\begin{array}{lllll}\text { No formal education } & 16 & 45.7 & 95 & 67.9\end{array}$

$\begin{array}{lllll}\text { Primary } & 12 & 34.3 & 40 & 28.6\end{array}$

Occupation

$\begin{array}{lllll}\text { Not eligible } & 7 & 20.0 & 15 & 10.7\end{array}$

$\begin{array}{lllll}\text { Farmer } & 20 & 57.1 & 80 & 57.1\end{array}$

$\begin{array}{lllll}\text { Student } & 4 & 11.4 & 30 & 21.4\end{array}$

$\begin{array}{lllll}\text { House wife } & 4 & 11.4 & 15 & 10.7\end{array}$

Marital status

$\begin{array}{lllll}\text { Not eligible } & 11 & 31.4 & 35 & 25.0\end{array}$

$\begin{array}{lllll}\text { Single } & 4 & 11.4 & 0 & 0.0\end{array}$

$\begin{array}{llll}\text { Married } & 20 & 57.1 & 105\end{array}$

Eating in other places than usual

$\begin{array}{lllll}\text { Yes } & 30 & 85.7 & 130 & 92.9\end{array}$

$\begin{array}{llll}\text { No } & 5 & 14.3 & 10\end{array}$

Drink raw milk

$\begin{array}{lllll}\text { Yes } & 23 & 65.7 & 76 & 54.3\end{array}$

$\begin{array}{lllll}\text { No } & 12 & 34.3 & 64 & 45.7\end{array}$

Eat raw meat

$\begin{array}{lllll}\text { Yes } & 14 & 40.0 & 25 & 17.9\end{array}$

$\begin{array}{lllll}\text { No } & 21 & 60.0 & 115 & 82.1\end{array}$

Having latrine

$\begin{array}{lllll}\text { Yes } & 30 & 85.7 & 110 & 78.6\end{array}$

$\begin{array}{lllll}\text { No } & 5 & 14.3 & 30 & 21.4\end{array}$

Using latrine

$\begin{array}{rrrrr}\text { Yes } & 22 & 73.3 & 80 & 64.0 \\ \text { No } & 8 & 26.7 & 45 & 36.0\end{array}$

Hand washing after defecation

$\begin{array}{rrrrr}\text { Yes } & 5 & 14.3 & 100 & 71.4 \\ \text { No } & 30 & 85.7 & 40 & 28.6\end{array}$

Hand washing before eating

$\begin{array}{lllll}\text { Yes } & 15 & 42.9 & 105 & 75.0\end{array}$

Cleaning material for feeding utensils

$\begin{array}{lrrrr}\text { Water only } & 15 & 42.9 & 75 & 53.6 \\ \text { Water with soap } & 5 & 14.2 & 40 & 28.6 \\ \text { Water with ash } & 15 & 42.9 & 25 & 17.9\end{array}$

9

7

6.4

3.6

6

7

4

.1

.3

\section{9}

2.1

78.6
21.4

64.0 36.0 
Table 1 (continued)

\begin{tabular}{|c|c|c|c|c|}
\hline \multirow[t]{3}{*}{ Characteristics } & \multicolumn{4}{|c|}{ Respondents status } \\
\hline & \multicolumn{2}{|l|}{ Cases } & \multicolumn{2}{|l|}{ Controls } \\
\hline & Number & Percentage & Number & Percentage \\
\hline \multicolumn{5}{|c|}{ Sources of drinking water } \\
\hline Pipe & 30 & 85.7 & 105 & 75.0 \\
\hline Well & 5 & 14.3 & 35 & 25.0 \\
\hline \multicolumn{5}{|c|}{ Treat water with chemicals/boil for drinking } \\
\hline Yes & 10 & 28.6 & 45 & 32.1 \\
\hline No & 25 & 71.4 & 95 & 67.9 \\
\hline \multicolumn{5}{|c|}{ Dispose of garbage } \\
\hline Pit & 10 & 28.6 & 55 & 39.3 \\
\hline Open field & 25 & 71.4 & 85 & 60.7 \\
\hline
\end{tabular}

\section{Discussion}

Food poisoning outbreak was occurred among lunch ceremony participants in Dewachefa woreda. This is consistent with the definition of food poisoning outbreak [5]. The etiology of this outbreak was bacteria because the laboratory results showed that pus cells this is one of the indications of bacterial infection. This outbreak specifically might be caused by Salmonella and Escherichia coli because of smaller number pus cells of 20 per high power field in the laboratory results.

The highest attack rate was at age of $>44$ years. This might be due to the fact that persons whose age $>44$ may be influenced by cultures of eating raw meat and drinking raw milk.

The finding of multivariable analysis revealed that eating raw meat, drinking raw milk, not hand washing before meal, materials use to clean food utensils (using soap) and source of drinking water (well water) were independent predictors of food poisoning. People who ate raw meat were almost 11 times more likely had food poisoning illness than people who did not eat raw meat. This is inline with the study conducted in Pima County [8]. This might due to the fact that raw meat has potential to carry foodborne bacteria that can cause illness [1]. The person who prepared the meat might not wash his/ her hands which may lead contamination of meat that impose food poisoning illness.

People who drank raw milk were almost 5 times more likely had food poisoning than people who did not drink raw milk. This is similar with the study conducted in western Sweden [8]. This could be due to unpasturazed milk has the potential to carry bacteria which cause food poisoning illness $[1,4]$. The milk might be contaminated by bacteria through contamination of the materials in which milk was collected or stored.

This study showed that people who had not hand washing before meal were almost 13 times more likely develop food poisoning illness than who had hand washing before meal. This might be due to contamination of hand with bacteria which leads food poisoning illness through the ingestion of bacteria.

Moreover, those who had been using well water for drinking were almost 11 more likely had food poisoning illness than who had been using pipe water for drinking. This evidence was supported by the study conducted in Pima County [7]. This might be due to the reason that well water would be contaminated with food poisoning agent. Persons who used Water with soap to clean food utensils were almost $94 \%$ less likely contracting food poisoning than persons who had used ash for cleaning food utensils. This might due to the fact that soap is the detergent that could clean food poisoning microorganizm.

\section{Conclusion}

Food poisoning outbreak was occurred among lunch ceremony participants in Gure and Qelo kebeles of

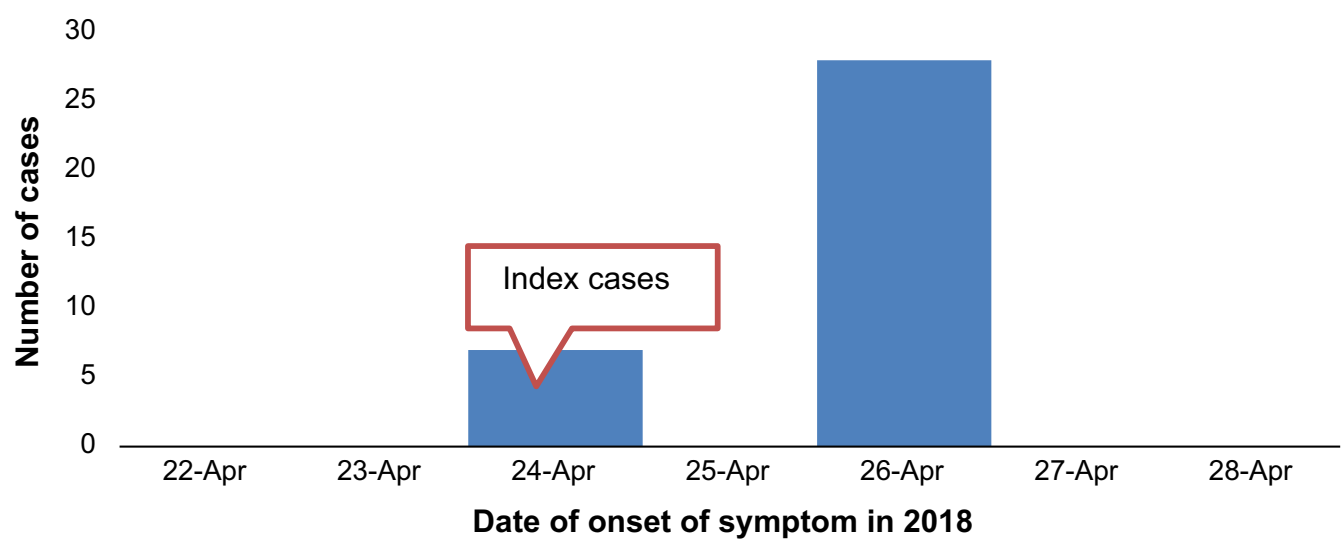

Fig. 1 Food poisoning outbreak Epi curve by date of onset in Dewachefa woreda, Oromia Zone, Amhara Region, Ethiopia, 2018 
Table 2 Multivariable analysis of factors associated with food poisoning outbreak in Dewachefa, Oromia Zone, Amhara Region, Ethiopia, 2018

\begin{tabular}{|c|c|c|c|c|c|}
\hline \multirow[t]{2}{*}{ Variables } & \multicolumn{2}{|c|}{ Respondent status } & \multirow[t]{2}{*}{ COR $(95 \% \mathrm{Cl})$} & \multirow[t]{2}{*}{ AOR $(95 \% \mathrm{Cl})$} & \multirow[t]{2}{*}{$p$-value } \\
\hline & Case & Control & & & \\
\hline \multicolumn{6}{|l|}{ Sex } \\
\hline Female & 14 & 75 & 1 & 1 & \\
\hline Male & 21 & 65 & $2.89(1.01-12.14)$ & $3.57(1.37-9.32)$ & $0.009^{*}$ \\
\hline \multicolumn{6}{|l|}{ Eating raw meat } \\
\hline No & 21 & 115 & 1 & 1 & \\
\hline Yes & 14 & 25 & $3.07(2.20-50.41)$ & $11.04(3.03-40.17)$ & $0.000^{*}$ \\
\hline \multicolumn{6}{|l|}{ Drinking raw milk } \\
\hline No & 12 & 64 & 1 & 1 & \\
\hline Yes & 23 & 76 & $1.61(0.91-10.13)$ & $4.81(1.42-16.23)$ & $0.011^{*}$ \\
\hline \multicolumn{6}{|c|}{ Hand washing after defecation } \\
\hline No & 30 & 40 & $15.0(0.65-9.12$ & $5.23(0.12-10.24)$ & 0.09 \\
\hline Yes & 5 & 100 & 1 & 1 & \\
\hline \multicolumn{6}{|c|}{ Hand washing before eating } \\
\hline No & 20 & 35 & $4.00(2.75-9.23$ & $13.42(3.63-49.72)$ & $0.000^{*}$ \\
\hline Yes & 15 & 105 & 1 & 1 & \\
\hline \multicolumn{6}{|c|}{ Cleaning materials for feeding utensils } \\
\hline Water only & 15 & 75 & $0.08(0.02-0.42$ & $0.06(0.01-0.25)$ & $0.000^{*}$ \\
\hline Water with soap & 5 & 40 & $0.05(0.01-0.40)$ & $0.06(0.01-0.32)$ & $0.000^{*}$ \\
\hline Ash & 15 & 25 & 1 & 1 & $0.001^{*}$ \\
\hline \multicolumn{6}{|l|}{ Dispose of garbage } \\
\hline Pit & 10 & 55 & 1 & 1 & \\
\hline Open field & 25 & 85 & $1.62(0.07-5.60)$ & $1.01(0.06-4.54)$ & 0.08 \\
\hline \multicolumn{6}{|c|}{ Sources of drinking water } \\
\hline Pipe & 30 & 105 & 1 & 1 & \\
\hline Well & 5 & 35 & $9.25(6.01-70.90$ & $11.50(1.96-67.49)$ & $0.007^{*}$ \\
\hline
\end{tabular}

*Statistical significance ( $p$-value $<0.05)$

Dewachfa woreda. The results of this study indicate that sex of study participants, eating raw meat, drinking raw milk, hand washing before eating, materials use to clean food utensils and source of drinking waters were factors of food poisoning outbreak. Therefore, health education should be strength about food handling practice during lunch ceremony.

\section{Limitation of the study}

This outbreak did not show specific etiologic agent because of inavailability other e.g. culture etc.) laboratory services in the hospital. The source of contamination of food was not identified due to inavailability of food sample.

\section{Abbreviations}

AOR: adjusted odds ratio; Cl: confidence interval; COR: crude odds ratio; EC: Ethiopian calendar; PHEM: Public Health Emergency Management; SD: standard deviation; SPSS: statistical package for social science.

\section{Acknowledgements}

We would like to acknowledge Ethiopian Public health Institute and Oromia Zone Health department. We would also like to extend our thanks to data collectors, supervisors and study participants.

\section{Authors' contributions}

MK wrote study design, data entry, analyzed the data, and drafted paper. SW approved the design and the study. Both authors read and approved the final manuscript.

\section{Funding}

Not applicable.

Availability of data and materials

The data sets generated during the current study are available from corresponding author on reasonable request.

Ethics approval and consent to participate

Ethical clearance was obtained from Oromia Zone Health department Ethical review committee. Supportive letter was sought from Dewachefa 
Health Office. Informed Written consent was obtained from each participant. Informed written agreement was also obtained from a parent or guardian on behalf of the participants under the age of 16 years. The study participants had the right to refuse in the study or withdraw at any time during the interview was respected. The information obtained from the study participant was maintained its confidentiality by not writing name of the study participants on the questionnaire paper. All cases were managed before interviewed.

\section{Consent for publications}

Not applicable.

\section{Competing interests}

The authors declare that they have no competing interests.

\section{Author details}

${ }^{1}$ Resident of Field Epidemiology, Department of Epidemiology and Biostatistics, College of Medicine and Health Science, Bahir Dar University, Bahir Dar, Ethiopia. ${ }^{2}$ Felege Hiote Specialized Referral Hospital, Bahir Dar, Ethiopia.

Received: 20 February 2019 Accepted: 24 June 2019

Published online: 02 July 2019

\section{References}

1. Davis CP. food poisoning. 2018. https://www.emedicinehealth.com/ food_poisoning/article_em.htm\#what_foods_usually_cause_food_poiso ning. Accessed 27 Apr 2018
2. Marissa Selner WY, Kathryn W. Food poisoning. 2017. https://www.healt hline.com/health/medical-team. Accessed 23 Apr 2018.

3. Sifferin A. Food poisoning. 2015. https://time.com/3768003/35100 0-people-die-of-food-poisoning-globally-every-year/. Accessed 27 Apr 2018.

4. Wedro B. Food poisoning. 2016. https://www.medicinenet.com/script/ main/alphaidx.asp?p=a_2. Accessed 20 Apr 2018.

5. WHO. Foodborne disease outbreaks: guidelines for investigation and control. Geneva: World Health Organization; 2008. p. 146.

6. Elshafie S. An outbreak of food poisoning after a major sport event: the role of PulseNet International. J Med Microb Diagn. 2007. https://doi. org/10.4172/2161-0703-C1-011.

7. Pogreba-Brown K, Ernst K, Woodson L, Harris RB. Determining risk factors of a non-point source outbreak of campylobacter cases using case-case and case-control studies. Epidemiology (sunnyvale). 2015;5:203. https:// doi.org/10.4172/2161-1165.1000203.

8. Studahl A, Andersson Y. Risk factors for indigenous campylobacter infection: a Swedish case-control study. Epidemiol Infect. 2000;125:269-75.

9. CDC. Foodborne illnesses and germs. 2018. https://www.cdc.gov/foods afety/foodborne-germs.html. Accessed 20 Apr 2018.

10. Dewachefa woreda Annual plan. 2018.

\section{Publisher's Note}

Springer Nature remains neutral with regard to jurisdictional claims in published maps and institutional affiliations.
Ready to submit your research? Choose BMC and benefit from:

- fast, convenient online submission

- thorough peer review by experienced researchers in your field

- rapid publication on acceptance

- support for research data, including large and complex data types

- gold Open Access which fosters wider collaboration and increased citations

- maximum visibility for your research: over $100 \mathrm{M}$ website views per year

At $\mathrm{BMC}$, research is always in progress.

Learn more biomedcentral.com/submissions 